\title{
Origin and Distribution of Polycyclic Aromatic Hydrocarbons (PAHs) in Surface Water of Suez Gulf
}

\author{
M.M. Emara, N.A. Farid", E.A. El-Sabagh ${ }^{* *}$, O.E. Ahmed ${ }^{* \#}$ \\ and E.M. Kamal** \\ Chemistry Department, Faculty of Science (Boys) Al-Azhar \\ University, "Egyptian Petroleum Research Institute and \\ ${ }^{* *}$ Chemistry Department, Faculty of Science (Girls) Al-Azhar \\ University, Nasr city, Cairo, Egypt.
}

\begin{abstract}
TE SUEZ Canal is the passage to the international trade between east and west, thus several waste pollutants are easily disposed and dumped into the boundaries of the studied area. The pollutants vary from raw sewage, oil spills, and industrial effluents to garbage which has tremendous impacts on the marine environment. Most of these sources in the investigated area mainly occurred from the human activities, e.g. Industrial wastes, domestic draining of the Suez City and ship's oil. Distribution and origin of polycyclic aromatic hydrocarbons of (PAHs) in the collected water samples revealed the origin of (PAHs) is petrogenic and pyrogenic or mixture of (petrogenic and pyrogenic). Levels of PAHs varied between (1.640, $39.139) \mu \mathrm{g} / \mathrm{L}$ and $(0.7317,21.9373) \mu \mathrm{g} / \mathrm{L}$ for summer and winter, respectively. These results indicate high level of contamination. It is recommended that more effort and rules should be carried out in order to govern, prevent or even minimize the sources of pollutants.
\end{abstract}

Keywords: Polycyclic aromatic hydrocarbon (PAHs), Surface seawater, Petrogenic, Pyrogenic, Mixture of petrogenic and pyrogenic and Suez Gulf.

Hydrocarbons are a wide spread class of environmental chemical pollutants ${ }^{(1)}$ which enter the marine environment through natural pathways and anthropogenic processes. Natural sources include forest fire, natural petroleum seeps and post depositional transformation of biogenic precursors. The most important anthropogenic sources are petrogenic and pyrogenic, the latter usually being largely prevalent in aquatic environments. Anthropogenic sources include urban runoff, sewage disposal, industrial effluents, oil production and transport activities. Polycyclic aromatic hydrocarbons (PAHs) a class of ubiquitous contaminants with two or more fused aromatic rings are mainly introduced into the environment via anthropogenic processes ${ }^{(2)}$, such as the combustion of fossil fuels and the direct release of oil and oil products with a smaller contribution arising from the forest fires and agricultural burn off. Anthropogenic inputs of PAHs have caused significant accumulation of PAHs in the marine environment ${ }^{(3)}$. PAHs are known to enter marine environment through the spillage of petroleum, atmospheric fallout and urban runoff; upon entering the aquatic system PAHs distribute between different phases including truly

\#Corresponding author: dr.omaymamosa@yahoo.com 
dissolved, colloids, suspended particulate matter, surface sediment and biota. The way in which PAHs are distributed between these different phases is controlled by their intrinsic physicochemical properties including solubility, vapour pressure and lipophilicety. Because of their low water solubility and hydrophobicity, they tend to adsorb to particulate material and deposit in the sediments .In this form they are more persistent to biodegradation in comparison to dissolved PAHs. The degradation intensity differs depending on biological, chemical and physiochemical Parameters (4). Earlier studies indicate that hydrophobic organic compounds such as PAHs are often enriched in the sea surface and sediments. Accumulation of PAHs in sediments can be remobilized in the sea water and become bio-available to indigenous aquatic organisms. Concentrations of PAHs at the sea surface and in sediments are of toxicological importance to both bentnic and pelagic marine organisms. Thus accumulation of pollutants represents a potential hazard to the organisms. As pollutants they are of great concern since some of them have been identified as carcinogenic and mutagenic. PAHs can induce oxidative stress and oxidative DNA damage through metabolic activation and the generation of reactive oxygen species ${ }^{(5,6)}$. Polycyclic aromatic hydrocarbon toxicity is very structurally dependent; with isomers varying from being non toxic to extremely toxic. Toxicity of these substances depends upon the number and configuration of the benzene rings and the presence and the position of their substituent ${ }^{(7)}$. Many high molecular mass PAHs are known to be carcinogenic and mutagenic (Fig.1 and Table 1). The composition of PAHs usually reflects the sources that produced the PAH. Some molecular indexes play a major role in establishing the origin of PAHs in marine water and sediments ${ }^{(8)}$. PAHs isomeric composition is temperature dependent because it is governed by thermodynamic properties in low temperature processes (e.g. formation of petroleum) or by kinetic factors in high temperature processes (e.g. pyrolysis of organic matter ). On the other hand, petrogenic contamination is characterized by the predominance of the lower molecular weight fraction, while the higher molecular weight PAHs prevails in pyrolytic PAHs, ${ }^{(9)}$.

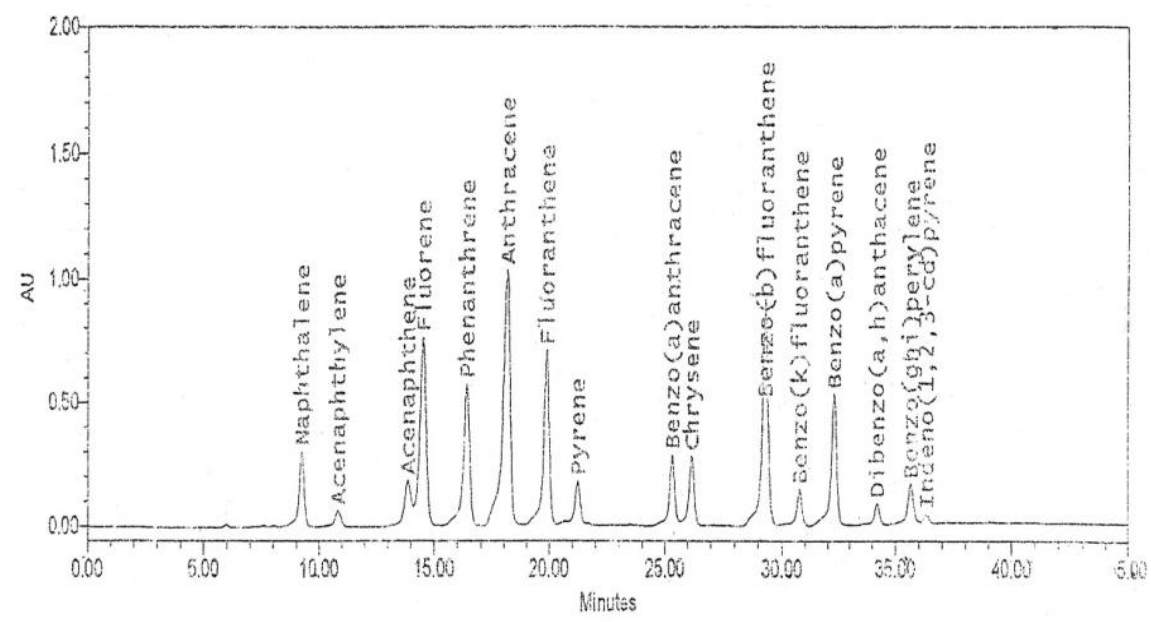

Fig. 1. Fluorescence of PNAs on Reverse phase Column PEPAHs/102.6 by $250 \mathrm{~mm}^{(10)}$.

Egypt. J. Chem. 56, No. 4 (2013) 
TABLE 1. Definition of each PAHs compounds in term of aromatic ring and carcinogenicity.

\begin{tabular}{|c|c|c|c|}
\hline $\begin{array}{r}\text { Aromatic } \\
\text { ring } \\
\end{array}$ & PAFS compounds & Structure & carcinogenicity \\
\hline 2- Ring & Naphtalene (Nap) & & -- \\
\hline 3-Ring & $\begin{array}{l}\text { Acenaphthylene(A) } \\
\text { Acenaphthene(Ace) } \\
\text { Phenanthrene(Phe) } \\
\text { Flourene(F) } \\
\text { Anthracene(Ant) }\end{array}$ & & -..- \\
\hline 4Ring & $\begin{array}{l}\text { Fluorantkane(Flu) } \\
\text { Pyrene(Pyr) } \\
\text { Benzo\{a\}anthracen(BaA) } \\
\text { Chrysene(Chr) }\end{array}$ & & + \\
\hline 5-Ring & $\begin{array}{l}\text { Benzo\{b\}fluoranthene(BbF) } \\
\text { Benzo\{K\}luoranthene(BKF) } \\
\text { Benzo\{a) Pyrene(BAP) } \\
\text { Dibenzo }\{\text { a,h\}anthracen(DahA) }\end{array}$ & & ++ \\
\hline 6-Ring & $\begin{array}{l}\text { Benzo }\{g h i\} \text { perlyene(Bp) } \\
\text { Indeno }\{1,2,3-c d\} \text { perlyen(IP) }\end{array}$ & & + \\
\hline
\end{tabular}

Fig. 1. Fluorescence of PNAs on Reverse phase Column PEPAHs $/ 102.6$ by $250 \mathrm{~mm}^{(10)}$. 


\section{Materials and Methods}

\section{Samples locations}

Table 2 shows the studied sites, their locations, activities and distance from Suez harbor.

TABLE 2. Studied sites, their locations, activities and distance from Suez Harbor.

\begin{tabular}{|c|l|l|c|}
\hline $\begin{array}{c}\text { Site } \\
\text { No. }\end{array}$ & \multicolumn{1}{|c|}{ Locations } & \multicolumn{1}{c|}{ Activities for each site } & $\begin{array}{c}\text { Distance } \\
\text { from Suez } \\
\text { Harb.(km) }\end{array}$ \\
\hline 1 & Suez Harbor. & $\begin{array}{l}\text { Loading and discharge, marine } \\
\text { transportation ,including tanker } \\
\text { operations }\end{array}$ & $2(\mathrm{~km})$ \\
\hline 2 & Al-Nasr oil Company & petroleum refinery of the crude oil & $5(\mathrm{~km})$ \\
\hline 3 & Inlet of Suez Oil Company & petroleum refinery of the crude oil & $7(\mathrm{~km})$ \\
\hline 4 & Outlet of Suez Oil Company. & petroleum refinery of the crude oil & $9(\mathrm{~km})$ \\
\hline 5 & $\begin{array}{l}\text { Outlet of Electrical Station } \\
\text { Company. }\end{array}$ & $\begin{array}{l}\text { Industrial treatment- Unit for domestic } \\
\text { sewage treatment }\end{array}$ & $10(\mathrm{~km})$ \\
\hline 6 & Fertilizer Factory & Unit for domestic sewage treatment & $18(\mathrm{~km})$ \\
\hline 7 & Al-Osra beach & Oil residue and solid wastes & $20(\mathrm{~km})$ \\
\hline 8 & Al-Melaha beach & Oil residue and solid wastes & $21(\mathrm{~km})$ \\
\hline
\end{tabular}

Harb: harbor, km: Kilometer.

\section{Collection of waste water samples}

The samples are collected seasonally from the different sites in the studied area as described in Table 2. The wastewater samples were taken from the drainages using plastic water sampler for waste water analysis, the sample size was (3L.) for the petroleum analysis and cleaned before use; they were rinsed several time in $0.1 \mathrm{~N}$ hydrochloric acid for several days and then rinsed and protected in diluted acid to prevent degradation of oil to give proper result of analysis. During the period of study, the wastewater samples are collected from two sides of the location and mixed to make composite sample which represent one station. The study was done seasonally and samples collected twice from the studied sites one in summer season 7-2009 and another one in winter season 22010.

\section{Extraction of petroleum oil from seawater samples}

Apparatus

-Separating funnel.

-Round bottom flask.

Solvents

-Concentrated hydrochloric acid (Adwic).

-Carbon tetrachloride (Adwic). 
Procedure

$100 \mathrm{ml}$ of the seawater sample was shaken with $100 \mathrm{ml}$ of carbon tetrachloride in a separating funnel for 15 min. After 30 seconds agitation and 3 min settling period, the aqueous layer was discarded. The process was repeated until all of seawater sample has been extracted. The obtained extract was dried using anhydrous sodium sulphate $(30 \mathrm{~g})$.

The extract was then transferred to a weighted beaker and finally evaporated by electrical furnace at $60{ }^{\circ} \mathrm{C}$ till constant weight ${ }^{(6)}$.

The oil content was calculated as: ug of oil/L $=\frac{(\mathrm{A}-\mathrm{B}) \times 10^{(6)}}{\mathrm{L}}$ $\mathrm{mL}$ of water sample

where: A \&B are the weight of flask after and before extraction.

High performance liquid chromatography Analysis (HPLC)

All oil extracted from the studied samples was analyzed using HPLC technique ${ }^{(11)}$.

Apparatus

Water HPLC 600, Auto sampler 616 plus, Dual Absorbance Detector 2487, attached to computerized system with Millennium 32 software.

Condition for operation

Sample: $1 \mu \mathrm{I}$

Column: Supelcosill LC-PAHs $.15 \mathrm{~cm}, 4.6 \mathrm{~mm}$ ID, $5 \mu \mathrm{m}$ particles

Mobile phase: Acetonitrite: water 50:50 for $5 \mathrm{~min}$.Changed gradually to $100 \%$ acetonitrile in the near $25 \mathrm{~min}$.

Flow Rate: 0-2 $\mathrm{min} ., 0-2 \mathrm{ml} / \mathrm{min}$.2-45 $\mathrm{min} .1 .0 \mathrm{ml} / \mathrm{min}$.

Detector: U.V $254 \mathrm{~nm}$.

\section{Result and Discussion}

The studied areas include Suez harbor, industrial zone in Suez and beaches in Ismailia city. These areas received pollutants from the shipping inputs which arise mainly from operational activities and from deliberating discharges of waste and water tankers. Oil is the most obvious contaminant in Suez Canal. Dumping and accidents also contribute, but much less than in shelf waters. Other chemical contaminants from the synthetic organic compounds are produced from the disposal of agricultural drains along the boundaries of the lakes and bay, as well as more directly via pipelines and dumping operations. Sewage disposal, industry, and agriculture are the sources of nutrients. Waters were taken to cover most of the contaminated sites in studied area in two trips. 
Seasonal variation and distribution patterns of total PAHs in surface seawater

Eight surface seawater samples were collected during summer and winter $7 / 2009$ and 212010, respectively in the Gulf of Suez, and analyzed by HPLC (Table 3 and Fig. 2). The total PAHs concentrations in surface seawater of the Gulf of Suez differ markedly in the summer and winter season's .The concentrations of total PAHs in summer ranged from 1.640 to $39.139 \mu \mathrm{g} / \mathrm{L}$. Highest concentrations was found at Inlet of Suez Petroleum Company, and the lowest concentration was recorded at Al-Melaha beach. Whereas, the concentration of total PAHs in surface seawater in winter ranged from 0.732 upto $21.937 \mu \mathrm{g} / \mathrm{L}$, the highest concentration was observed at the Fertilizer company $21.937 \mu \mathrm{g} / \mathrm{L}$, and the lowest concentration $(0.731 \mu \mathrm{g} / \mathrm{L})$ was recorded at the Suez harbor (Table 3 and Fig 2). Several previous studies ${ }^{(12,13)}$ were carried out in order to determine the seasonal variability of PAH concentrations in seawater. The results suggest that seasonal variation in PAH concentrations is generally connected to temperature, lower concentrations of PAH were observed during summer, while higher concentrations during winter. The researches ${ }^{(13,14)}$ observed that decreasing concentrations in summer could be a result of accelerated degradation due to the higher water temperature that affects the rate by which PAHs are degraded by micro-organisms or due to higher photooxidation. Additionally, other previous work also, suggested that seasonal variation in PAH concentration could be also attributed to hydrological and meteorological conditions .In contrast to previous studies ,the results of our study show an average higher total PAH concentrations in summer compared to those in winter. Higher concentrations of PAHs detected in summer could be attributed to; PAHs of different degradation products present in surface seawater, while in general, the levels of PAHs determined in previous studies took into account only resolved PAH compounds. In accordance with our expectations, higher concentrations of PAHs were obtained in semi-enclosed sites such as marine, harbors and petroleum companies. Results obtained proved that such location showed the most polluted ones. The reason lies in the more intensive pollution and limited circulation of seawater leading to higher accumulation of pollutants, arising from boats engine losses, atmospheric deposition and urban runoff. On the other hand, the offshore sites are less subjected to pollution pressure and at the same time, the mixing of water mass leads to the dilution of dissolved, dispersed compounds ${ }^{(3)}$.

TABLE 3. Seasonal variation of total PAHs concentration $(\mu \mathrm{g} / \mathrm{L})$ in surface seawater at different sampling stations in Suez Gulf.

\begin{tabular}{|c|l||c||c||}
\hline \multirow{2}{*}{ S.No. } & \multicolumn{1}{c||}{ Location } & \multicolumn{2}{c||}{ Concentration } \\
\cline { 2 - 3 } & & Summer & Winter \\
\hline 1 & Suez harbor & 21.98 & 0.732 \\
\hline 2 & Al-Nasr Oil Comp. & 7.845 & 8.432 \\
\hline 3 & Inlet of Suez Oil Comp. & 39.1392 & 16.758 \\
\hline 4 & Outlet of Suez Oil Comp. & 29.5748 & 2.29406 \\
\hline 5 & Ataqqa electrical st. & 2.870 & 6.3855 \\
\hline 6 & Fertilizer company & 10.92 & 21.9373 \\
\hline 7 & Al-Osra beach & 19.72 & 10.2824 \\
\hline 8 & Al-Melaha beach & 1.640 & 21.21 \\
\hline
\end{tabular}

Concentration: ug/l.

Egypt. J. Chem. 56, No. 4 (2013) 


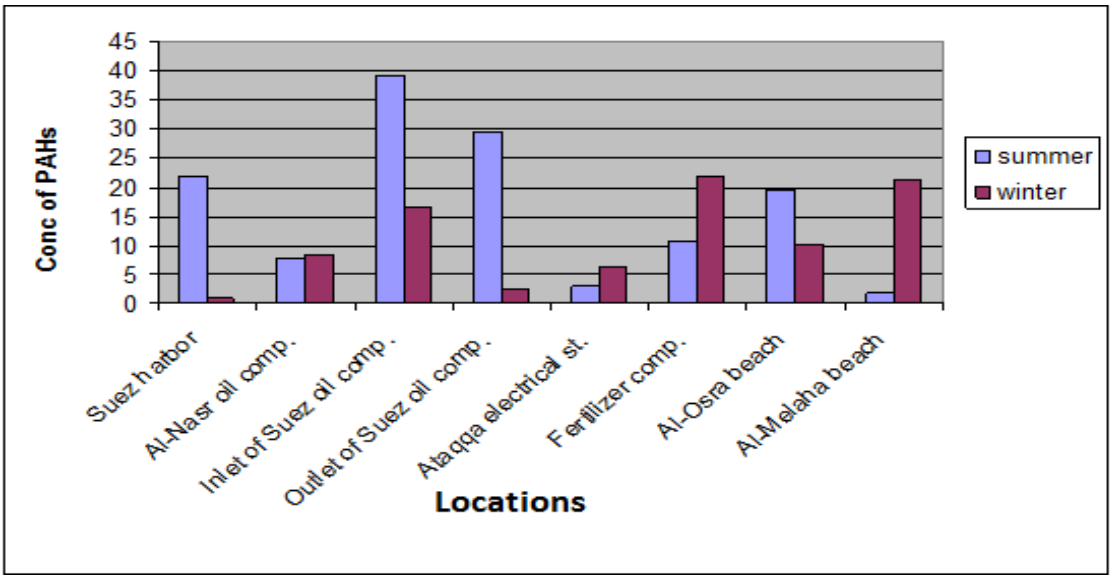

Fig. 2. Histogram representing seasonal variation of total PAHs concentration $\mu \mathrm{g} / \mathrm{L}$.

Concentration of individual PAH in surface seawater

The composition of PAHs in a particular sample usually reflects the source that produces the PAHs. There are three major types of PAH which differ by their genesis petrogenic, pyrogenic and biogenic. All samples (Tables 4,5 and Fig. 3,4) are characterized by the presence of low poly-aromatic hydrocarbons (di, tri-aromatic ring) and 10 PAHs compounds, (tetra-penta and hexa-aromatic ring).HPAHs are more carcinogenic than either lower or longer ring system ${ }^{(15)}$ PAHs with 2-3 rings are generally of petrogenic origin, including crude oil and its refined products ${ }^{(16)}$.

Di-aromatic ring PAHs show the presence of naphthalene at sites $(2,3,7 \& 8)$ for summer and $(3,4,6$ and 7) for winter water samples suggesting fresh petroleum pollution .Close values (2.036) \& (2.290) $\mu \mathrm{g} \backslash \mathrm{L}$, respectively were observed for sites $(3 \& 4)$ in winter and predominance of Al-Osra beach site (7) (18.90) $\mu \mathrm{g} \backslash \mathrm{L}$.

Tri-aromatic rings PAHs were below the detection limit at some samples except for sites $(2,3)$, which have Acenaphthylene (A) values $(0.7084 \& 0.2406$ $\mu \mathrm{g} / \mathrm{L})$ for summer and $(0.5903,1.4207 \mu \mathrm{g} \backslash \mathrm{L})$ for sites $(6 \& 7)$ in winter water samples. Acenaphthene (Ace) recorded high value at site (2) $(6.5982 \mu \mathrm{g} / \mathrm{L})$ in summer, while close values for sites $(3,6)(5.875$ and $5.6764 \mu \mathrm{g} / \mathrm{L})$ in winter season. Phenanthrene (phe) suggested matching values between sites $(6,8)$ and $(2,3)$, they have values $0.025,0.02 \mu \mathrm{g} / \mathrm{L}$ and $0.1706 \& 0.2649 \mu \mathrm{g} / \mathrm{L}$ for summer. Also, good matching for sites $(2,3)$ which have values $0.0342,0.0266 \mu \mathrm{g} / \mathrm{L}$ at winter water samples (Tables $4 \& 5)$. Sites $(7,8)$ and (3) have values $(0.1622$, $0.194 \mu \mathrm{g} / \mathrm{L}) \&(3.478 \mu \mathrm{g} / \mathrm{L})$ for summer and winter season, respectively, while the rest samples were below the detection limit, for Flourene $(\mathrm{F})$. On the other hand, Anthracene (Ant) recorded values for all samples except for sites $(3,6)$ at summer and $(1,2,4,7 \& 8)$ were below the detection limit in winter. 
Tetra -aromatic rings PAHs with 4-6 ring hydrocarbons are generally of pyrogenic origin and generated by the combustion of fossil fuel and of recent organic material ${ }^{(16)}$. High concentrations Fluoranthene, Pyrene and Chrysene (Chr), Benzo (a) pyrene (BAP) for summer and winter season samples suggest a pyrogenic origin.

Penta-aromatc rings Only sample (4) have Benzo(k)Fluoranthene (BKF) with value $(3.004) \mu \mathrm{g} / \mathrm{L}$ whereas sites $(3,4 \& 6)$ have values $29.377,25.436 \&$ $10.44 \mu \mathrm{g} / \mathrm{L}$, respectively from Benzo(a)Pyrene (BAP) for summer water samples and $6.2252,11.8658 \& 1.7446 \mu \mathrm{g} / \mathrm{L}$ for sites $(2,6 \& 8)$, respectively in winter. Indeed, each of Suez petroleum inlet and Al-Melaha beach sites ( $3 \& 8)$ have Dibenz, (a,h) anthracene (DahA) $2.012 \& 15.1861 \mu \mathrm{g} / \mathrm{L}$ for summer and winter season, respectively .

Six aromatic rings: Compounds from Benz (ghi) Perlyene (BP) and Indeno $(1,2,3$-cd) perlyene (IP) are present in most samples with the predominance of (BP) $(21.77 \mu \mathrm{g} / \mathrm{L})$ for Suez Gulf in summer season. High poly- aromatic compounds (HPAHs) have high carcinogenic effect and show that the samples suffer high weathering effects.

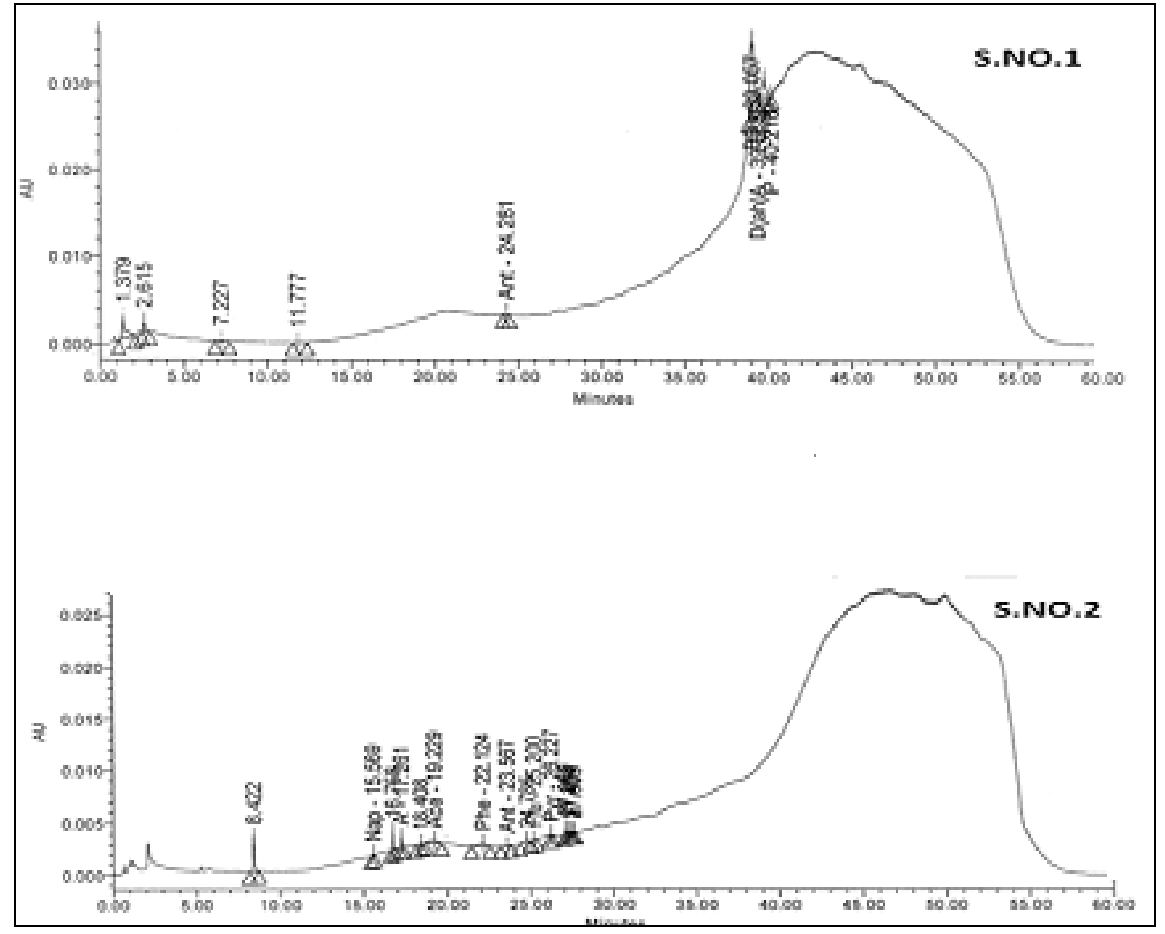

Fig. 3. HPLC diagram for oil extracted from Suez Gulf summer water samples.

Egypt. J. Chem. 56, No. 4 (2013) 


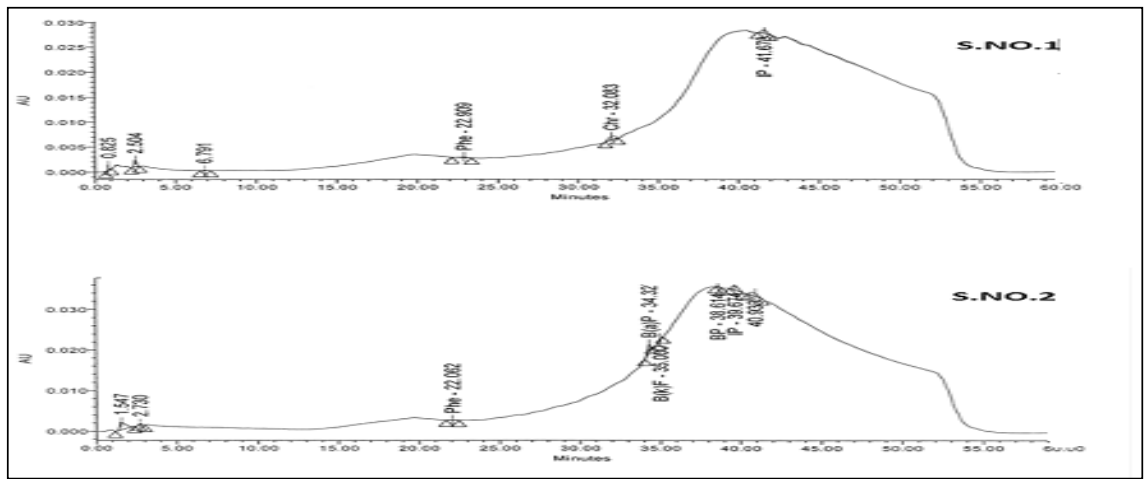

Fig. 4. HPLC diagram for oil extracted from Suez Gulf winter water samples.

TABLE 4. Concentration of individual PAH $(\mu \mathrm{g} / \mathrm{L})$ in the oil extracted from summer water samples.

\begin{tabular}{|c|c|c|c|c|c|c|c|c|c|}
\hline \multirow{2}{*}{\multicolumn{2}{|c|}{$\begin{array}{l}\text { Locations } \\
\text { PAH }\end{array}$}} & \multirow{3}{*}{$\begin{array}{c}\text { S.NO.1 } \\
\text { N.D }\end{array}$} & \multirow{3}{*}{$\begin{array}{c}\text { S.NO.2 } \\
0.2814\end{array}$} & \multirow{3}{*}{$\begin{array}{c}\text { S.NO.3 } \\
0.6765\end{array}$} & \multirow{3}{*}{$\begin{array}{c}\text { S.NO.4 } \\
\text { N.D }\end{array}$} & \multirow{3}{*}{$\begin{array}{c}\text { S.NO.5 } \\
\text { N.D }\end{array}$} & \multirow{3}{*}{$\begin{array}{c}\text { S.NO.6 } \\
\text { N.D }\end{array}$} & \multirow{3}{*}{$\begin{array}{r}\text { S.NO.7 } \\
18.90\end{array}$} & \multirow{3}{*}{$\begin{array}{l}\text { S.NO.8 } \\
0.3141\end{array}$} \\
\hline & & & & & & & & & \\
\hline 2Ring & Nap. & & & & & & & & \\
\hline & Total & N.D & 0.2814 & 0.6765 & N.D & N.D & N.D & 18.90 & 0.314 \\
\hline \multirow{5}{*}{ 3Ring } & A. & N.D & 0.7084 & 0.2406 & N.D & N.D & N.D & N.D & N.D \\
\hline & Ace. & N.D & 6.5982 & 1.9090 & N.D & N.D & N.D & 3.095 & N.D \\
\hline & Phe. & N.D & 0.1706 & 0.2649 & N.D & 0.0928 & 0.025 & 0.00705 & 0.020 \\
\hline & F. & N.D & N.D & N.D & N.D & N.D & N.D & 0.1622 & 0.194 \\
\hline & Ant. & 0.0129 & 0.0046 & N.D & 0.0279 & 0.00295 & N.D & 0.00514 & 0.010 \\
\hline & Total & 0.0129 & 7.481 & 2.4145 & 0.0279 & 0.0957 & 0.025 & 0.4838 & 0.225 \\
\hline \multirow{5}{*}{ 4Ring } & Flu. & N.D & 0.040 & 1.8822 & 0.2328 & N.D & N.D & 0.0239 & 0.102 \\
\hline & Pyr. & N.D & 0.042 & 0.7722 & 0.2370 & N.D & N.D & 0.2545 & 0.079 \\
\hline & $\mathbf{B a A}$ & N.D & N.D & 0.1518 & N.D & N.D & N.D & 0.0384 & N.D \\
\hline & Chr. & N.D & N.D & N.D & N.D & 0.182 & N.D & 0.0171 & 0.048 \\
\hline & Total & ND & 0.083 & 2.8062 & 0.4698 & 0.182 & ND & 0.3339 & 0.2301 \\
\hline \multirow{4}{*}{ 5Ring } & Bbf & N.D & N.D & N.D & N.D & 0.169 & N.D & N.D & 0.060 \\
\hline & Bkf & N.D & N.D & N.D & 3.0039 & N.D & N.D & N.D & N.D \\
\hline & BAp & N.D & N.D & 29.377 & 25.436 & 0.154 & 10.44 & N.D & N.D \\
\hline & BahA & 0.131 & N.D & 2.012 & ND & 0.849 & ND & N.D & N.D \\
\hline & Total & 0.131 & ND & 31.389 & 28.4399 & 1.172 & 10.44 & ND & 0.060 \\
\hline \multirow{2}{*}{ 6Ring } & Bp & 21.77 & N.D & N.D & 0.5836 & 1.405 & N.D & N.D & N.D \\
\hline & Ip & 0.068 & N.D & 1.853 & 0.0536 & 0.014 & 0.454 & N.D & 0.811 \\
\hline & Total & 21.84 & N.D & 1.853 & 0.63729 & 1.419 & 0.454 & N.D & 0.811 \\
\hline Total PAHS & & 21.98 & 7.845 & 39.1392 & 29.5748 & 2.870 & 10.92 & 19.72 & 1.640 \\
\hline
\end{tabular}

Concentration :( $\mu \mathrm{g} / \mathrm{L}), \quad$ N.D: not detection (under the limit of detection). 
TABLE 5. Concentration of individual PAH $(\mu \mathrm{g} / \mathrm{L})$ in the oil extracted from winter water samples.

\begin{tabular}{|c|c|c|c|c|c|c|c|c|c|}
\hline \multicolumn{2}{|c|}{$\begin{array}{l}\text { Locations } \\
\text { NO. PAHs }\end{array}$} & S.NO.(1) & S.NO.(2) & S.NO.(3) & S.NO.(4) & S.NO.(5) & S.NO.(6) & S.NO.(7) & S.NO.(8) \\
\hline 2Ring & Nap. & N.D & N.D & 2.036 & 2.2904 & N.D & 1.2798 & 0.8628 & N.D \\
\hline & Total & N.D & N.D & 2.036 & 2.2904 & N.D & 1.2798 & 0.8628 & N.D \\
\hline \multirow[t]{2}{*}{ 3Ring } & $\begin{array}{l}\text { A. } \\
\text { Ace. } \\
\text { Phe. } \\
\text { F. } \\
\text { Ant. }\end{array}$ & $\begin{array}{l}\text { N.D } \\
\text { N.D } \\
0.0803 \\
\text { N.D } \\
\text { N.D }\end{array}$ & $\begin{array}{l}\text { N.D } \\
\text { N.D } \\
0.0342 \\
\text { N.D } \\
\text { N.D }\end{array}$ & $\begin{array}{l}\text { N.D } \\
5.875 \\
0.0266 \\
3.478 \\
0.0234\end{array}$ & $\begin{array}{l}\text { N.D } \\
\text { N.D } \\
\text { N.D } \\
\text { N.D } \\
\text { N.D }\end{array}$ & $\begin{array}{l}\text { N.D } \\
\text { N.D } \\
1.0876 \\
\text { N.D } \\
0.0308\end{array}$ & $\begin{array}{l}0.5903 \\
5.6764 \\
0.8503 \\
\text { N.D } \\
0.1273\end{array}$ & $\begin{array}{l}\text { N.D } \\
2.5862 \\
\text { N.D } \\
\text { N.D } \\
\text { N.D }\end{array}$ & $\begin{array}{l}1.4207 \\
\text { N.D } \\
\text { N.D } \\
\text { N.D } \\
\text { N.D }\end{array}$ \\
\hline & Total & 0.0803 & 0.0342 & 9.403 & ND & 1.1184 & 7.2443 & 2.5862 & 1.4207 \\
\hline \multirow[t]{2}{*}{ 4Ring } & $\begin{array}{l}\text { Flu. } \\
\text { Pyr. } \\
\text { BaA } \\
\text { Chr. }\end{array}$ & $\begin{array}{l}\text { N.D } \\
\text { N.D } \\
\text { N.D } \\
0.1918\end{array}$ & $\begin{array}{l}\text { N.D } \\
\text { N.D } \\
\text { N.D } \\
\text { N.D }\end{array}$ & $\begin{array}{l}\text { N.D } \\
0.0843 \\
4.1788 \\
0.00950\end{array}$ & $\begin{array}{l}\text { N.D } \\
0.00245 \\
0.00121 \\
\text { N.D }\end{array}$ & $\begin{array}{l}1.3524 \\
2.1076 \\
0.5209 \\
0.1351 \\
\end{array}$ & $\begin{array}{l}\text { N.D } \\
0.3297 \\
\text { N.D } \\
\text { N.D }\end{array}$ & $\begin{array}{l}3.3665 \\
\text { N.D } \\
\text { N.D } \\
\text { N.D }\end{array}$ & $\begin{array}{l}2.0055 \\
\text { N.D } \\
\text { N.D } \\
\text { N.D }\end{array}$ \\
\hline & Total & 0.1918 & N.D & 4.2706 & 0.00366 & 4.116 & 0.3297 & 3.3695 & 2.0055 \\
\hline \multirow[t]{2}{*}{ 5Ring } & $\begin{array}{l}\text { Bbf } \\
\text { Bkf } \\
\text { BAp } \\
\text { BahA }\end{array}$ & $\begin{array}{l}\text { N.D } \\
\text { N.D } \\
\text { N.D } \\
\text { N.D }\end{array}$ & $\begin{array}{l}\text { N.D } \\
0.7546 \\
6.2252 \\
\text { N.D }\end{array}$ & $\begin{array}{l}0.1741 \\
0.8746 \\
\text { N.D } \\
\text { N.D }\end{array}$ & $\begin{array}{l}\text { N.D } \\
\text { N.D } \\
\text { N.D } \\
\text { N.D }\end{array}$ & $\begin{array}{l}0.4491 \\
\text { N.D } \\
\text { N.D } \\
\text { N.D }\end{array}$ & $\begin{array}{l}\text { N.D } \\
1.2177 \\
11.8658 \\
\text { N.D }\end{array}$ & $\begin{array}{l}\text { N.D } \\
3.1367 \\
\text { N.D } \\
\text { N.D }\end{array}$ & $\begin{array}{l}\text { N.D } \\
0.8531 \\
1.7446 \\
15.1861\end{array}$ \\
\hline & Total & N.D & 6.9771 & 1.0488 & N.D & 0.4491 & 13.0835 & 3.1367 & 17.7838 \\
\hline \multirow[t]{2}{*}{ 6Ring } & $\begin{array}{l}\text { Bp } \\
\text { Ip }\end{array}$ & $\begin{array}{l}\text { N.D } \\
0.4596\end{array}$ & $\begin{array}{l}0.2697 \\
1.1510\end{array}$ & $\begin{array}{l}\text { N.D } \\
\text { N.D }\end{array}$ & $\begin{array}{l}\text { N.D } \\
\text { N.D }\end{array}$ & $\begin{array}{l}\text { N.D } \\
0.7020\end{array}$ & $\begin{array}{l}\text { N.D } \\
\text { N.D }\end{array}$ & $\begin{array}{l}0.3272 \\
\text { N.D }\end{array}$ & $\begin{array}{l}\text { N.D } \\
\text { N.D }\end{array}$ \\
\hline & Total & 0.4596 & 1.4207 & N.D & N.D & 0.7020 & N.D & 0.3272 & N.D \\
\hline $\begin{array}{l}\text { Total } \\
\text { PAHS }\end{array}$ & & 0.7317 & 8.432 & 16.758 & 2.29406 & 6.3855 & 21.9373 & 10.2824 & 21.21 \\
\hline
\end{tabular}

Concentration :( $\mu \mathrm{g} / \mathrm{L})$, N.D: not detection (under the limit of detection).

Egypt. J. Chem. 56, No. 4 (2013) 
Distinguishing between pyrogenic and petrogenic origin hydrocarbon in Suez Gulf

Several methods can be used to determine the most probable sources o PAHs ${ }^{(3)}$. In many studies, ${ }^{(16,2)}$ the sources of PAHs in various environmental samples were determined by various molecular diagnostic ratios. One of the most used approaches is to compare the sum of several pyrogenic PAHs (4-6 ring PAHs) with a group of petrogenic PAHs (2-3 ring PAHs), since the 2-ring and 3-ring PAHs are more abundant in petroleum, while highly condensed PAHs (4-6 PAHs) are significant combustion products pyrogenic sources, such as the combustion - derived particles present in urban atmospheric dust were depleted in low molecular weight 2-3 ring PAHs (LPAHs)and enriched in high molecular weight 4-6 ring PAHs (HPAHs), which led to an LPAHs $\backslash$ HPAHs ratio $<1$. petrogenic sources, such as fuel oil or light refined petroleum products, were dominated by low molecular weight PAHs and have LPAHs $\backslash$ HPAHs ratio $>1$. Indeed, the higher the LPAHs \ HPAHs ratio, the higher the prevalence of petrogenic sources ${ }^{(17)}$. The sources of PAHs may be assessed also by using the ratios of individual PAH concentrations ${ }^{(18)}$. Different authors use different methods for such purposes, widely used ratios are Fluoranthene to pyrene (Flu/pyr), and phenanthrene to anthrancene (phe /Ant). The Flu/pyr ratio $>1$ suggests pyrogenic sources, while Flu/pyr $<1$ indicates petrogenic sources ${ }^{(19)}$. The ratio between phenanthrene and anthrancene was also extensively used to infar the nature of PAH pollution ${ }^{(8)}$. A phe/Ant ratio $<10$ suggests pyrogenic origin while, contamination from petrogenic sources is characterized by phe/Ant > 10.Besides the above mentioned ratio, some other $\mathrm{PAH}$ isomer ratios, such anthracene to anthracene plus phenanthrene Ant /(Ant+phe), benzo (a) anthracene to benzo(a) anthracene plus chrysene $\mathrm{BaA} /(\mathrm{BaA}+\mathrm{Chr})$, Fluoranthene to Fluoranthene plus pyrene Flu / Flu+pyr, Indeno(1,2,3-cd)pyrene to indeno (1,2,3-cd) pyrene plus benzo $(\mathrm{g}, \mathrm{h}, \mathrm{i})$ perylene Ip /(Ip+BP) and benzo (a)pyrene to benzo $(\mathrm{g}, \mathrm{h}, \mathrm{i})$ perylene $(\mathrm{BAp} / \mathrm{Bp})$ have been developed to a more detailed interpretation of $\mathrm{PAH}$ composition and the inference of possible sources ${ }^{(20)}$. Tables 6,7 show that phe/Ant ratio for S.NO.(5)31.45 and $35.311 \mu \mathrm{g} / \mathrm{L}>10$ indicating mainly petrogenic origin, for summer and winter seasons, and also S.NO.(2) for summer water samples. The rates of Fluoranthene / pyrene (Flu/pyr) indicate the origin of PAHs. A predominance of Fluoranthene over pyrene is characteristic of pyrolytic sources, whilest in PAHs petrogenic origin, pyrene is more abundant than Fluoranthene. Table 6 shows that PAHs of samples $(2,4$ and 7$)$ have mainly petrogenic origin while samples $(3,8)$ have mainly pyrolytic origin for summer season, but Table 7 for winter S.NO. (5) have petrogenic origin, while the rest of sample under low concentrations. Benzo (a) pyrene (BAP) over Diabenzo (a,h) anthracene (DahA) recorded high value for S.NO.(3) (14.500) and low value for S.NO.(5)(2.1813) in summer season. On the other hand, S.NO.(8) recorded $0.1148 \mu \mathrm{g} / \mathrm{L}$ in winter season and most samples suffering from high weathering effect in two seasons, nso the ratio under low detection. It has suggested that a ratio of Benzo(a) anthracene / Chrysene $(\mathrm{BaA} / \mathrm{Chr})>0.9$ indicating pyrolytic sources while, a value $\leq 0.4$ suggest petrogenic origin ${ }^{(3)}$. The ratio of S.NO. (7) have value 2.24 
$\mu \mathrm{g} / \mathrm{L}$ indicating pyrolytic sources (Table 6) and also ,S. NO. $(5,7)$ (3.855and $2.24 \mu \mathrm{g} / \mathrm{L}$ ) in winter season, but Inlet of Suez oil company represented value $(0.00006 \mu \mathrm{g} / \mathrm{L})$ suggested petrogenic origin (Table 7) . Al-Osra beach and Attaqa electrical station recorded values $(0.4453 \& 0.2593 \mu \mathrm{g} / \mathrm{L})$ for $\mathrm{Chr} / \mathrm{BaA}$ ratio which denotes petrogenic origin (Tables $6 \& 7$ ), on the contrary, Inlet of Suez oil company have value $4.1883 \mu \mathrm{g} / \mathrm{L}$ indicating pyrogenic sources (Table 6). Indeed, Benzo(a) pyrene (BaP) over Benzo (g,h,i) perlyene (BP), Bap/Bp ratio is used to exhibit the pollution from the Gulf traffic through the port as from the industry and sewage out falls from the city of Suez Gulf. Also, its semi-enclosed position and shallowness is an exceptionally sensitive ecosystem which is strongly influenced by human activities. The Gulf's peculiar geomorphologic and hydrologic conditions make it prone to the accumulation of pollutants which mainly enter the Gulf environmental through anthrogenic activities ,the relatively high ratios were recorded at sites $(4,2)(89.68 \mu \mathrm{g} / \mathrm{L})$ and $(23.08 \mu \mathrm{g} / \mathrm{L})$ for summer and winter season, respectively, Tables $6 \& 7$ suggesting values $>0.6$ are most due to the influence of intensive sea traffic through the ports as well as industrial and sewage discharges from the coastal cities in this region Attaqa electrical station site (5) which recorded low value $(0.1069 \mu \mathrm{g} / \mathrm{L})$ explaining that the offshore area around the city of the Gulf unpolluted part, this agreement with low concentrations of PAH in surface seawater in this area. Besides the above mentioned ratios some other PAHs isomer ratio such as Ant $\backslash$ (Ant + phe), BaA / $(\mathrm{BaA}+\mathrm{Chr})$, Flu / (Flu+pyr) and Ipy / (Ipy+BpE) have been developed for a more detailed interpretation of PAHs composition and interference of possible sources ${ }^{(20)}$ Tables $6 \& 7$ display values for Ant / Ant+phe ratio less than 0.1 except for S.NO. $(7,8)$ for summer season $0.4215,0.3333 \mu \mathrm{g} / \mathrm{L}$ in Table 6 , also S.NO. $(3,6)$ $0.4680,1.1049 \mu \mathrm{g} / \mathrm{L}$ indicating pyrogenic origin in Table 7. BaA / BaA+Chr exhibit pyrogenic sources for S.NO (7) \& $(3,5)$ which have values $(0.6918 \mu \mathrm{g} / \mathrm{L})$ and $(0.9977,0.7940 \mu \mathrm{g} / \mathrm{L})$ for summer and winter seasons, also the values $>0.4$ suggested pyrogenic origin while, $<0.4$ indicating petrogenic sources for Flu / (Flu+pyr) ratio ${ }^{(6)}$. S.NO. $(2,4)($ Table 6) exhibit values $0.4878,0.4955 \mu \mathrm{g} / \mathrm{L}$ suggests fuel combustion from petrogenic origin, whereas S.NO.3 $(0.7090 \mu \mathrm{g} / \mathrm{L})$ and $8(0.5635 \mu \mathrm{g} / \mathrm{L})$ indicating grass, cool and wood combustion from pyrogenic sources $^{(3)}$. Indeed, Ip $/ \mathrm{Ip}+\mathrm{Bp}$ recorded values $<0.2$ petrogenic and $>0.2$ pyrogenic sources for summer and winter season samples. Table 7 shows high value $>0.5$ for $\mathrm{Ip} / \mathrm{Ip}+\mathrm{Bp}$ ratio at S.NO.2 $(0.8101 \mu \mathrm{g} / \mathrm{L})$ which denotes pyrogenic sources from grass, wood and cool combustion. Lower molecular weight compounds (LPAHs) are abundant in petrogenic (PAHs), which can easily undergo weathering as compared to the higher molecular weight (HPAHs). Thus attention has been paid to the distribution of Low and high molecular weight (PAHs) as a reliable tool origin of (PAHs). Studies have shown that high ( $\Sigma$ LPAHs / $\Sigma$ HPAHs) ratios $>1$ often indicate (PAHs) with petrogenic origin predominate sources, while low ( $\Sigma$ LPAHs / $\Sigma$ HPAHs) ratios suggest PAHs of pyrolytic origin (21), so Tables $6 \& 7$ display values for (6LPAHs / 10HPAHs) ranged between $(0.00006$ to $93.522 \mu \mathrm{g} / \mathrm{L})$ and $(0.0040$ up to $572.5 \mu \mathrm{g} / \mathrm{L})$ for summer and winter seasons samples, respectively .

Egypt. J. Chem. 56, No. 4 (2013) 
TABLE 6. PAHs parameter used to detect the origin of PAHs for summer water samples.

\begin{tabular}{|c|c|c|c|c|c|c|c|c|c|c|c|c|c|}
\hline $\begin{array}{l}\text { S.N } \\
\text { o. }\end{array}$ & Phe/Ant & $\mathrm{Flu} / \mathrm{Pyr}$ & BAP/DahA & $\mathrm{BaA} / \mathrm{Chr}$ & $\mathrm{Chr} / \mathrm{BaA}$ & $\mathrm{BAp} / \mathbf{B p}$ & $\begin{array}{c}\text { Ant } \\
/ \text { (Ant+phe) }\end{array}$ & $\begin{array}{c}\mathrm{BaA} \\
(\mathrm{BaA}+\mathrm{Chr})\end{array}$ & $\begin{array}{c}\text { Flu/ } \\
\text { (Flu+Pyr) }\end{array}$ & $\begin{array}{c}\mathbf{I P} / \\
\mathbf{I P}+\mathbf{B P}\end{array}$ & 6LPAHs & 10HPAHs & $\begin{array}{l}\text { 6LPAHs } \\
/ 10 \mathrm{HPAHs}\end{array}$ \\
\hline 1 & N.D & N.D & N.D & N.D & N.D & N.D & N.D & N.D & N.D & 0.0031 & 0.0129 & 21.975 & 0.0006 \\
\hline 2 & 36.49 & 0.9523 & N.D & N.D & N.D & N.D & 0.0262 & N.D & 0.4878 & N.D & 7.7624 & 0.083 & 93.522 \\
\hline 3 & N.D & 2.437 & 14.600 & N.D & N.D & N.D & N.D & N.D & 0.7090 & N.D & 3.091 & 36.048 & 0.0857 \\
\hline 4 & N.D & 0.9822 & N.D & N.D & N.D & 89.68 & N.D & N.D & 0.4955 & 0.0841 & 0.0279 & 29.546 & 0.0009 \\
\hline 5 & 31.45 & N.D & 0.1813 & N.D & N.D & 0.1096 & 0.0303 & N.D & N.D & 0.0098 & 0.0957 & 2.775 & 0.0344 \\
\hline 6 & N.D & N.D & N.D & N.D & N.D & N.D & N.D & N.D & N.D & N.D & 0.025 & 10.894 & 0.0022 \\
\hline 7 & 1.371 & 0.0939 & N.D & 2.24 & 0.4453 & N.D & 0.4215 & 0.6918 & 0.0858 & N.D & 19.389 & 0.333 & 58.225 \\
\hline 8 & 1.951 & 1.290 & N.D & N.D & N.D & N.D & 0.3333 & N.D & 0.5635 & N.D & 0.5392 & 1.101 & 0.4897 \\
\hline
\end{tabular}

TABLE 7. PAHs parameter used to detect the origin of PAHs for winter water samples.

\begin{tabular}{|c|c|c|c|c|c|c|c|c|c|c|c|c|c|}
\hline S.No & Phe/Ant & Flu/Pyr & BAP/DahA & BaA/Chr & Chr/BaA & BAp/Bp & $\begin{array}{c}\text { Ant } \\
\text { (Ant+phe) }\end{array}$ & $\begin{array}{c}\text { BaA/ } \\
\text { (BaA+Chr) }\end{array}$ & $\begin{array}{c}\text { Flu/ } \\
\text { (Flu+Pyr) }\end{array}$ & $\begin{array}{c}\text { P/ } / \\
\text { IP+BP }\end{array}$ & $\mathbf{6 L P A H s}$ & $\mathbf{1 0 H P A H s}$ & $\begin{array}{c}\mathbf{6 L P A H s} \\
\text { /10HPAHs }\end{array}$ \\
\hline $\mathbf{1}$ & N.D & N.D & N.D & N.D & N.D & N.D & N.D & N.D & N.D & N.D & 0.0803 & 0.651 & 0.123 \\
\hline $\mathbf{2}$ & N.D & N.D & N.D & N.D & N.D & 23.08 & N.D & N.D & N.D & 0.8101 & 0.0342 & 8.397 & 0.0040 \\
\hline $\mathbf{3}$ & 1.1367 & N.D & N.D & 0.00006 & 4.1883 & N.D & 0.4680 & 0.9977 & N.D & N.D & 11.439 & 5.319 & 2.150 \\
\hline $\mathbf{4}$ & N.D & N.D & N.D & N.D & N.D & N.D & N.D & N.D & N.D & N.D & 2.290 & 0.0040 & 572.5 \\
\hline $\mathbf{5}$ & 35.311 & 0.641 & N.D & 3.855 & 0.02593 & N.D & 0.0275 & 0.7940 & 0.3908 & N.D & 1.118 & 5.267 & 0.212 \\
\hline $\mathbf{6}$ & 6.679 & N.D & N.D & N.D & N.D & N.D & 1.1049 & N.D & N.D & N.D & 8.524 & 13.413 & 0.635 \\
\hline $\mathbf{7}$ & N.D & N.D & N.D & 2.240 & N.D & N.D & N.D & N.D & N.D & N.D & 3.449 & 6.833 & 0.504 \\
\hline $\mathbf{8}$ & N.D & N.D & 0.1148 & N.D & N.D & N.D & N.D & N.D & N.D & N.D & 1.420 & 19.789 & 0.071 \\
\hline
\end{tabular}

PAHs parameter used to detect the origin of PAHs by $\mu \mathrm{g} / \mathrm{L}$, N.D: not determined. LPAHs'HPAHs $>1$ petrogenic, $<1$ pyrogenic, Flu/Flu+pyr $<0.4$ petrogenic $>0.4$ pyrogenic, Ant $/$ Ant + phe $<0.1$ petrogenic,$>0.1$ pyrogenic, Flu/pyr $<1$ petrogenic, $>1$ pyrogenic, Phe $/$ Ant $>10$ petrogenic, $<10$ pyrogenic, BaA $/ \mathrm{BaA}+\mathrm{chr}$ $<0.2$ petrogenic, $>0.35$ pyrogenic $\mathrm{BaA} /$ Chr 0.9 petrogenic, $<0.4$ pyrogenic, $\mathrm{Chr} / \mathrm{BaA}<1$ petrogenic, $>1$ pyrogenic, $\mathrm{BAp} / \mathrm{BP}<0.6$ petrogeni, $>0.6$ pyrogenic, Flu/flu+pyr $0.4-0.5$ petrogenic, $>0.5$ pyrog enic, Ipy//py+Bp $<0.2$ petrogenic, $>0.2$ pyrogenic, Ipy//py+BPE $0.2-0.5$ petrogenic, $>0.5$ pyrogenic, ${ }^{(3,14)}$. 
For better determination and demonstration LPAHs/HPAHs ratio against Flu/pyr ratio were examined in Table 8 and suggested by Brandli et al. ${ }^{(20)}$ the PAH cross plots of the ratios of LPAHs/HPAHs against Flu /pyr indicate different PAH origins, summer surface seawater S.No. (3,8) with LPAHs / HPAHs ratio $<1$ and Flu/pyr ratio $>1$ suggested pyrogenic origin, while S.No. $(4,5,1)$ with LPAHs $\backslash H P A H s<1$ and Flulpyr ratio $<1$ suggested mixed origin (pyrogenic and petrogenic) for summer and winter seasons samples ${ }^{(22)}$. The origin of PAHS in surface water samples were examined by phe/Ant against Flu/pyr ratios (Table 9), the phe/Ant ratio $<10$ and Flu / pyr ratio $>1$ found in summer water S.No. (3), and suggested contamination from combustion processes, while phe/Ant ratio $>10$ and Flu/pyr ratio $<1$ found in water S.No. $(2 \& 5)$ confirmed mixed origin ${ }^{(23)}$. The phe/Ant ratio against Flu/pyr ratio suggests mixed origin, while S.NO. (2\&5) indicates the predominance of petrogenic origin in summer and winter seasons, respectively. In order to determine PAHs sources in surface seawater where different ratios and plots show mixed origin, the ratios Ant/(Ant+phe) against Flu / (Flu / pyr) (Table 10), were previously reported in this study ${ }^{(24)}$.

TABLE 8. PAH ratios of seasonal surface seawater samples.

\begin{tabular}{|c|l|c|c|c|c|}
\hline \multirow{2}{*}{ S.NO. } & \multirow{2}{*}{ Locations } & \multicolumn{2}{c|}{ LPAHsLPAHs } & \multicolumn{2}{c|}{ Flu/Pyr } \\
\cline { 3 - 6 } & & Summer & Winter & Summer & Winter \\
\hline 1 & Suez harbor & 0.0006 & 0.123 & N.D & N.D \\
\hline 2 & Al-Nasr Oil Company. & 93.522 & 0.0040 & 0.9523 & N.D \\
\hline 3 & Inlet of Suez Oil Company. & 0.0857 & 2.150 & 2.437 & N.D \\
\hline 4 & Outlet of Suez Oil Company & 0.0009 & 572.5 & 0.98822 & N.D \\
\hline 5 & Ataqqa electrical station. & 0.0344 & 0.212 & N.D & 0.641 \\
\hline 6 & Fertilizer Factory & 0.0022 & 0.635 & N.D & N.D \\
\hline 7 & Al-Osra beach & 58.225 & 0.504 & 0.0939 & N.D \\
\hline 8 & Al-Melaha beach & 0.4897 & 0.071 & 1.290 & N.D \\
\hline
\end{tabular}

LPAHS: Low polyaromatic hydrocarbons, H PAHs: High polyaromatic hydrocarbons, Fiu: Fluorantheme: Pyr: Pyrene, N.D:

Not detection (under the limit of detection).

TABLE 9. Calculated ratios for source identification seasonal surface water samples.

\begin{tabular}{|l|l|c|c|c|c|}
\hline \multirow{2}{*}{ S.NO. } & \multicolumn{1}{|c|}{ Locations } & \multicolumn{2}{c|}{ Phe/Ant } & \multicolumn{2}{c|}{ Flu/Pyr } \\
\cline { 3 - 6 } & & Summer & Winter & summer & Winter \\
\hline 1 & Suez harbor & N.D & N.D & N.D & N.D \\
\hline 2 & Al-Nasr Oil Company. & 36.49 & N.D & 0.9523 & N.D \\
\hline 3 & Inlet of Suez Oil Company. & N.D & 1.1367 & 2.437 & N.D \\
\hline 4 & Outlet of Suez Oil Company & N.D & N.D & 0.98822 & N.D \\
\hline 5 & Ataqqa electrical station. & 31.45 & 35.311 & N.D & 0.641 \\
\hline 6 & Fertilizer Factory & N.D & 6.679 & N.D & N.D \\
\hline 7 & Al-Osra beach & 1.371 & N.D & 0.0939 & N.D \\
\hline 8 & Al-Melaha beach & 1.951 & N.D & 1.290 & N.D \\
\hline
\end{tabular}

Phe: Phenanthrene; Ant: Anthracene, Flu: Fluoranthene; Pyr: Pyrene, N.D: not detection (under the limit of detection).

Egypt. J. Chem. 56, No. 4 (2013) 
TABLE 10. Determination of PAH pollution sources of seasonal surface water samples.

\begin{tabular}{|c|l|c|c|c|c|}
\hline \multirow{2}{*}{ S.NO. } & \multicolumn{1}{|c|}{ Locations } & \multicolumn{2}{c|}{ AntlAnt+phe } & \multicolumn{2}{c|}{ FlulFlu+pyr } \\
\cline { 3 - 6 } & & Summer & Winter & summer & Winter \\
\hline 1 & Suez harbor & N.D & N.D & N.D & N.D \\
\hline 2 & Al-Nasr Oil Comp. & 0.0262 & N.D & 0.4878 & N.D \\
\hline 3 & Inlet of Suez Oil Company. & N.D & 0.4680 & 0.7090 & N.D \\
\hline 4 & Outlet of Suez Oil Company. & N.D & N.D & 0.4955 & N.D \\
\hline 5 & Ataqqa electrical station. & 0.0303 & 0.0275 & N.D & 0.3908 \\
\hline 6 & Fertilizer Factory & N.D & 1.1049 & N.D & N.D \\
\hline 7 & Al-Osra beach & 0.4215 & N.D & 0.0858 & N.D \\
\hline 8 & Al-Melaha beach & 0.3333 & N.D & 0.5635 & N.D \\
\hline
\end{tabular}

Anthracene phe: Phenanthrene; Flu: Fluoranthene; Pyr: Pyrene, N.D: not detection (under the limit of detection).

Distribution of PAHs (\%) in surface seasonal seawater according to their number of aromatic rings

The composition pattern of PAH by ring number is shown in Tables $11 \& 12$ and Fig. $5 \& 6$. Usually, low molecular weight PAHs predominate in seawater while high molecular weight PAHs predominate in sediment sample ${ }^{(3,24)}$. Such a difference in contaminant abundance by different PAH assemblages is expected due to at least two factors. First, the water column receives direct PAH inputs from various sources, including both petrogenic and pyrolytic. In the surface seawater of the Gulf of Suez, the petrogenic sources may be more widespread and dominate than pyrolytic ones, leading to the abundance of 3-ring PAHs in seawater. Second only those PAHs that are stable enough will reach the sediment bed. Such PAHs are quite likely to be of relatively high molecular mass and hence more resistant to degradation, evaporation and dissolution processes. In addition, processes such as biodegradation will attach PAHs leading to accumulation of those PAHs more resistant to degradation. Again, it is mainly the high molecular mass PAHs that are more stable. As a result, the water samples were dominated by different PAHs. Generally, the most abundant 2-3 ring compounds of phenanthrene, anthracene, acenaphthene and naphthalene were present in both summer and winter season samples. Predominance of low molecular weight PAH (2-3 ring PAHs) over high molecular weight PAHs (4-6 ring PAHs) in seawater is in accordance with some other studies ${ }^{(25)}$. 2-3ring PAHs showed dominance at S.NO (2, 7, 8 \& 3), respectively, with percentage between 0.09 to $98.9 \%$ for summer water samples (Table $11 \&$ Fig. 5). Whereas, winter samples recorded predominance for SNO. (4, 3, 6, $7 \& 8)$, respectively and exhibited percentage ranged between $0.41-99.8 \%$ (Table 12 \& Fig. 6). Beside, four ring PAHs suggest value ranged between 0.083 upto14.0 percentages for summer season. On the contrary, winter season samples represented an increasing percentage for 4-ring distribution at S.NO. $(5,7 \& 3)$ with values $(64.5,32.8$ and $25.5 \%$ ), respectively (Table 12 \& Fig. 6). Penta aromatic ring percentage of higher molecular weight, PAHs has been commonly observed in summer and winter season samples ranged between (0.59-96.16percent) and (6.3-83.8\%), respectively. Benzo(ghi) perlyene $(\mathrm{Bp})$ and Indeno $(1,2,3 \mathrm{~cd})$ perlyene in six ring compounds prevailed at sites (1,5and 8 ) with percentage $(99.36,49.4$ and $49.5 \%)$ for summer season, and recorded values ranged between (3.2 up to $62.8 \%$ ) for winter samples and dominance for S.NO.(1,2) $(62.8 \%$ and $16.9 \%)$, respectively (Tables 11,12 \& Fig. 5, 6) 
TABLE 11. Distribution of PAHs \% in surface seawater of the Suez Gulf according to number of aromatic rings for summer samples.

\begin{tabular}{|c|c|c|c|c|c|c|c|c|}
\hline Type of Ring & $\begin{array}{c}\text { S.NO. } \\
(\mathbf{1})\end{array}$ & $\begin{array}{c}\text { S.NO } \\
(\mathbf{2})\end{array}$ & $\begin{array}{c}\text { S.NO } \\
(\mathbf{3})\end{array}$ & $\begin{array}{c}\text { S.NO } \\
(\mathbf{4})\end{array}$ & $\begin{array}{c}\text { S.NO } \\
(\mathbf{5})\end{array}$ & $\begin{array}{c}\text { S.NO } \\
(\mathbf{6})\end{array}$ & $\begin{array}{c}\text { S.NO } \\
(\mathbf{7})\end{array}$ & $\begin{array}{c}\text { S.NO } \\
(\mathbf{8})\end{array}$ \\
\hline 2-3 ring & 0.06 & 98.9 & 7.89 & 0.09 & 3.3 & 0.22 & 98.2 & 32.7 \\
\hline 4-ring & N.D & 0.083 & 7.16 & 1.58 & 6.3 & N.D & 1.7 & 14.0 \\
\hline 5-ring & 0.59 & N.D & 80.19 & 96.16 & 40.8 & 95.6 & N.D & 3.6 \\
\hline 6-ring & 99.36 & N.D & 4.73 & 2.15 & 49.4 & 4.15 & N.D & 49.5 \\
\hline
\end{tabular}

N.D: Not Determined.

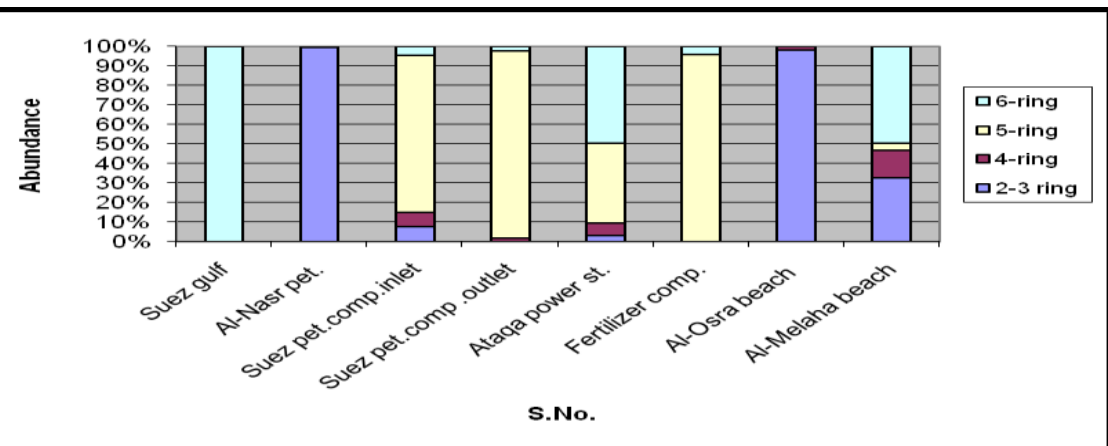

Fig. 5. Histogram represented the distribution of PAHs \% in surface seawater of the Suez Gulf according to number of aromatic rings for summer samples.

TABLE 12. Distribution of PAHs\% in surface seawater of the Suez Gulf according to number of aromatic rings for winter samples.

\begin{tabular}{|c|c|c|c|c|c|c|c|c|}
\hline Type of Ring & $\begin{array}{c}\text { S.NO } \\
(\mathbf{1})\end{array}$ & $\begin{array}{c}\text { S.NO } \\
(\mathbf{2})\end{array}$ & $\begin{array}{c}\text { S.NO } \\
(\mathbf{3})\end{array}$ & $\begin{array}{c}\text { S.NO } \\
(\mathbf{4})\end{array}$ & $\begin{array}{c}\text { S.NO } \\
(\mathbf{5})\end{array}$ & $\begin{array}{c}\text { S.NO } \\
(\mathbf{6})\end{array}$ & $\begin{array}{c}\text { S.NO. } \\
(\mathbf{7})\end{array}$ & $\begin{array}{c}\text { S.NO } \\
(\mathbf{8})\end{array}$ \\
\hline 2-3 ring & 11.0 & 0.41 & 68.3 & 99.8 & 17.5 & 38.9 & 33.5 & 6.7 \\
\hline 4-ring & 26.2 & N.D & 25.5 & 0.16 & 64.5 & 1.50 & 32.8 & 9.4 \\
\hline 5-ring & N.D & 82.8 & 6.3 & N.D & 7.03 & 59.6 & 30.5 & 83.8 \\
\hline 6-ring & 62.8 & 16.9 & N.D & N.D & 11.0 & N.D & 3.2 & N.D \\
\hline
\end{tabular}

N.D: Not Detected.

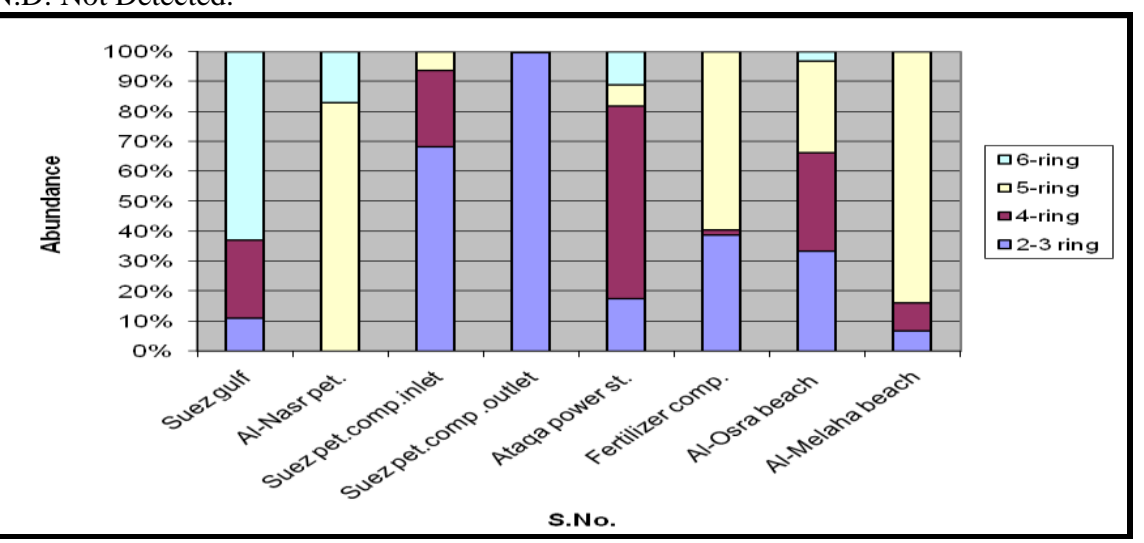

Fig. 6. Histogram represented the distribution of PAHs \%in surface seawater of the Suez Gulf according to number of aromatic rings for winter sample .

Egypt. J. Chem. 56, No. 4 (2013) 


\section{Conclusion and Recommendations}

The aim of the present study was to investigate and establish the pollution with PAHs in surface sea water of the Suez Gulf, Egypt, HPLC was applied as screening method for the determination of total PAHs in surface seawater across the range of estuaries ,marinas, coastal and offshore areas in order to identify hot spots and also, for the individual PAHs compounds identification at the most polluted sites .Because surface seawater samples often reflect the momental situation of $\mathrm{PAH}$ pollution which usually depends on hydrological and meteorological conditions. The study was focused on distribution, seasonal variation, composition and sources of PAHs in surface seawater of Suez Gulf. Different diagnostic ratios were applied to elucidate the sources of investigated compounds. Results of the present study provide information about the contamination of surface seawater, which are considered as one of the most dangerous group of environmental pollutants, in an industrial and very sensitive area in Egypt. The results of this study show seasonal concentration of TPAHs ranged between $(1.640-39.139 \mu \mathrm{g} / \mathrm{L})$ and $(0.7317-21.9373 \mu \mathrm{g} / \mathrm{L})$ for summer and winter, respectively, this will contribute to the better understanding of the state and sources of pollution with PAHs in the Suez Gulf. Because the Suez Gulf is used in many areas as a recipient of waste water from different sources; this study recommended that pollution control for wastewater disposing into it should be improved by separation of oils water Alsabourh before dumping into the Gulf, follow the accumulation of contaminants in the water and beaches to take the necessary precautions to reduce it, development of a system for rapid intervention in the event of oil disasters and serious commitment to the application of environmental law 1994 on the protection of water and beaches.

\section{References}

1.Valavanidis, A., Vlachogianni, Th., Triantafillaki, S., Dassenakies, M., Androutsos, F. and Scoullos, M., Polycyclic aromatic hydrocarbons in surface seawater and in indigenous mussels (Mytilus galloprovincialis) from coastal areas of the Saronikos Gulf ,Greece. Estuarial. Coastal and Shelf Science, 79,733-739 (2008).

2. Qiu, Y.W., Zhong, G., Liu, G. O., Guo, L. L., Li, X. D., Wai, O., Polycyclic aromatic hydrocarbons (PAHs)in the water column and sediment core of Deep Bay, South China. Estuarial .Coastal and Shelf Science, 83,60-66 (2009).

3. Ludvik, Penko., MSc. Thesis entitled, Polycyclic aromatic hydrocarbons in seawater and sediments of the Gulf of Trieste .Nova Garcia (2010).

4. Jovan-cicevic, B., Vrvic, M., Schwarzbauer, J., Wehner, H., Scheader, G. and Vitorovic, D., Organic-geochemical differentiation of petroleum type pollutants and study of their fate in Danube alluvial sediment and corresponding water (Pancevo oil refinery, Serbia). water. Air and Soil Pollution, 183,225-23, (2007).

5. Ohnishi, S. and Kawanishi, S., Double base lesions of D NA by metabolite of carcinogenic benzo (a) pyrene. Biochemical and Biophysical Research Communications, 290, 778 - 782 (2002). 
6. Mohamed, I.A., Thesis submitted for MSC, studied on water quality in selected area of Egypt, Azhar University (2012).

7. Harvey and Harvey, R.G., Polycyclic Aromatic Hydrocarbons, Wiley New York, 811 (1996).

8. Magi, E., Bianco, R., Ianni, C., Di carro, M., Distribution of polycyclic aromatic hydrocarbons in sediment of the Adriatic Sea. Environmental pollution.119, 91-98 (2002).

9. Zakaria, M.P., Takada, H., Tsutsumi, Si, Ohno, K. ,Yamada, J., Kouno, E. and Kumata, H., Distribution of polycyclic aromatic hydrocarbons (PAHs) in rivers and estuaries in Malasysia.a widespread input of petrogenic PAHs. Environmental Science and Technology, 36, 1907-1918 (2002).

10. Annual Book of ASTM. Standard-Water and Environmental Technology, standard Practices for extraction of tract elements from sediment.V11.02, water (11) D3974-81, P 573-585 (1999).

11. Shou-Fengchen, Richard A. Mowery, Vanessa A. Castleberry, Peter Van Walsum. G. and Kevin Chambills, High -performance liquid chromatography method for simultaneous determination of aliphatic products in biomass pretreatment hydrocarbons. Journal of Chromatography a, 1104, 54-61 (2006).

12. Halsall, C., Barrie, L.A., Fellini, P., Muir, D.C.G., Billeck, B. N., Lockhart, L., Rovinsky, F. Ya., Kononov, EYA. and Pastukhov, B., Spatial and temporal variation of polycyclic aromatic hydrocarbons in the arctic atmosphere. Environmental Science and Technology, 31, 3593-3599 (1997).

13. Witt, G., Occurrence and transport of polycyclic aromatic hydrocarbons in the water bodies of the Baltic Sea. Marine Chemistry, 79, 49-66 (2002).

14. Abd el-Rahman, M. Mousa, Nazik A. Farid and Omayma E. Ahmed, Contamination of water, sediment, tar ball and fishes by polyaromatic hydrocarbons (PAHs) in Alexandria Sea coasts. International Conference on Petroleum Mineral Resources, Egyptian Petroleum Research institute (2013).

15. Neff, J.M., Polycyclic aromatic hydrocarbons in the aquatic environment. fates and biological effects. 7-33, Applied Science, London, U. K. (1979).

16. Liu, Y., Chen, L., Jianful. Z., Qinghui, H., Zhiliang, Z. and Ttongwen. G., Distribution and sources of polycyclic aromatic hydrocarbons in surface sediments of river and estuary in Shanghai China. Environmental Pollution. 154, 298-305 (2008).

17. Wang, X.C.S. sum, S.Ma, H.O. and lu, Y., Sources and distribution of aliphatic polyaromatic hydrocarbons in sediments of Jia Ozou Bay, Quingdaeo, China. Marine Pollution Bulletin, 52, 129-138 (2006).

18. Katsoyiannis, A., Terzi, E. and Cai, Q. Y., On the use of PAH molecular diagnostic ratios in sewage sludge for the understanding of the PAH sources. It this use appropriate chemosphere, 69, 1337-1339 (2007).

Egypt. J. Chem. 56, No. 4 (2013) 
19. Kim, M., Kennicutt, It, M.C. and Qian, Y., Source characterization using compound composition and stable carbon isotope ratio and PAHs in sediments from lakes .harbore, and shipping waterway, Science of Total Environment, 289, 367-377 (2008).

20. Brandli, M., Bucheli, T. D., Kupper, T., Mayer, J., Stadelman F.X. and Taradellas, S., Fate of PCBS, PAHs and their sources characteristic ratio during composition and digestion of source-separated organic waste in full-scale plants. Environmental. Pollution, 520-528 (2007).

21. De Luca, G., Furesi, A., Micera, G., Panzanelli, A., Piu, P.C., Pilo, M. I., Spano, N., Halsall, C., Barrie, L.A., Fellini, P., Muir, D.C.G., Billeck, B.N., Lockhart, L., Rovinsky, F.Ya., Kononov, EYA. and Pastukhov, B., Spatail and temporal variation of polycyclic aromatic hydrocarbons in the arctic atmosphere. Environmental Science and Technology, 31, 3593-3599 (1997)

22. Sherif, Ali, Nour, Sh-El-Gendy, Yasser Moustafa and Salem A. Habib, Distributions ,sources and risk assessment of oil pollution and polycyclic aromatic hydrocarbons contamination in El-Lessan Area of Damietta River Nile Branch.12 $2^{\text {th }}$ International Conference in Petroleum ,Mineral Wealth and Development, 7-9, Feb. Cairo, Egypt, (2009).

23. Notar, M., Leskovsek, H. and Faganeli, J., Composition, distribution and sources of polycyclic aromatic hydrocarbons in sediments of the Gulf of Trieste, Northern Adriatic Sea. Marine Pollution Bulletin, 42, 36-44 (2001).

24. Cibic, T., Acquavita, A., Aleffi, F., Beltoso, N., Blasutto O., De vittor, C., Falconi, C., Fonda, J., Faresil, predonzani S., T Amberlich F. and Fonda umani, S. International approach to sediment pollution: a case study in the Gulf of Trieste. Marine Pollution Bulletin, 56, 1650-1657 (2008).

25. Health, E., Organic, N., Faganeli, J. and Covelli, S., Sedimentary record of polycyclic aromatic hydrocarbons in the Gulf of Trieste (Northern Adriatic Sea).water, air and soil pollution. Focus, 6, 241-250 (2006). 


\section{أصل إنتثار المركبات الأروماتيه متعددة الحلقات فى المياة السطحية

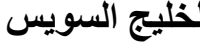

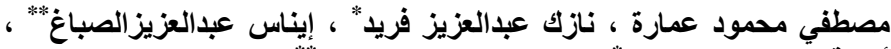

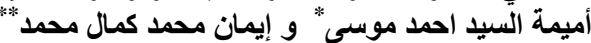

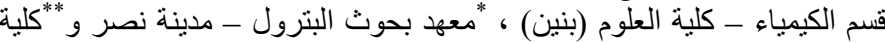

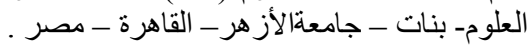

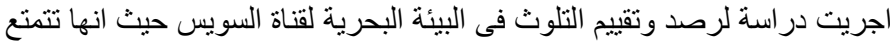

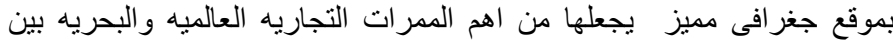

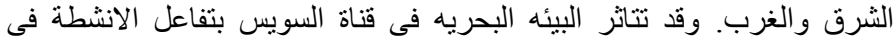

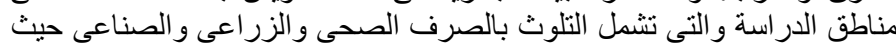

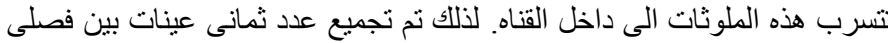

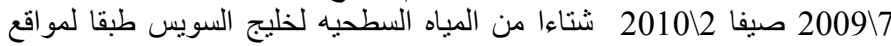

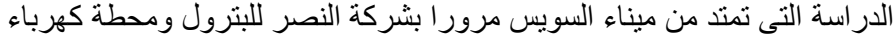

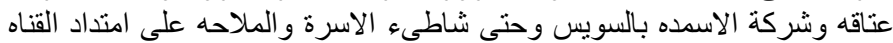

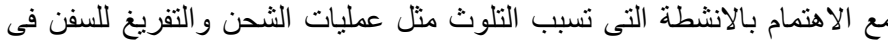

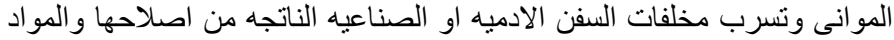

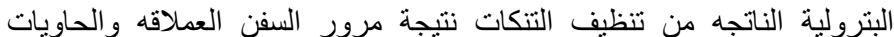

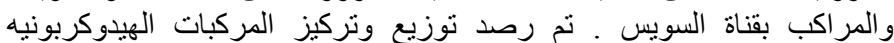

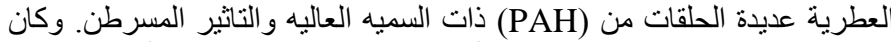

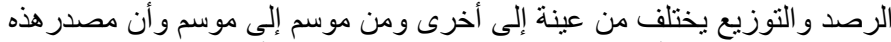

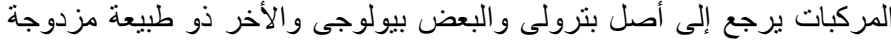

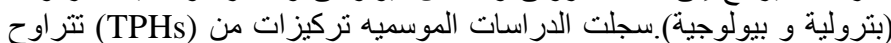

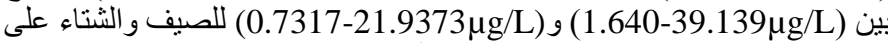

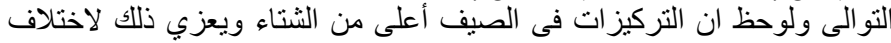

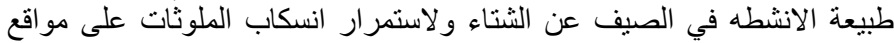

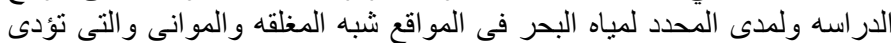

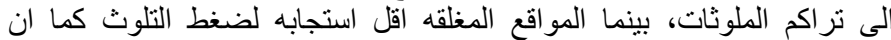

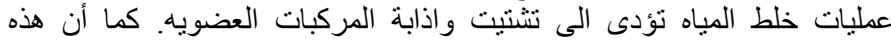

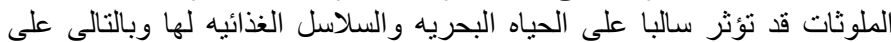

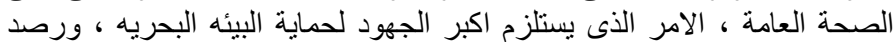

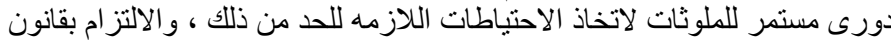

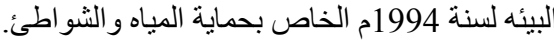

